\title{
Synthesis and spectral characterization of selective pyridine compounds as bioactive agents
}

\author{
Shaban A. A. Abdel-Raheema ${ }^{\text {* }}$, Adel M. Kamal El-Dean ${ }^{b}$, Reda Hassanien ${ }^{c}$, Mohamed E. A. El- \\ Sayed $^{a}$, Mostafa Sayed ${ }^{\mathrm{c}}$ and Aly A. Abd-Ella ${ }^{\mathrm{d}}$
}

${ }^{a}$ Soil, Water, and Environment Research Institute, Agriculture Research Center, Giza, Egypt

${ }^{b}$ Chemistry Department, Faculty of Science, Assiut University, 71516 Assiut, Egypt

${ }^{c}$ Chemistry Department, Faculty of Science, New Valley University, El-Kharja, 72511, Egypt

${ }^{d}$ Plant Protection Department, Faculty of Agriculture, Assiut University, 71526 Assiut, Egypt

\begin{tabular}{l} 
C H R O N I C L E \\
\hline Article history: \\
Received October 18, 2020 \\
Received in revised form \\
January 28, 2021 \\
Accepted February 14, 2021 \\
Available online \\
February 14, 2021 \\
\hline Keywords: \\
Synthesis \\
Evaluation \\
Cowpea aphid \\
Activity \\
Acetamiprid \\
\end{tabular}

\begin{abstract}
A B S T R A C T
Starting from 3-cyano-4,6-distyrylpyridin-2(1H)-thione (1), the compound $N$-(4chlorophenyl)-2-((3-cyano-4,6-distyrylpyridin-2-yl)thio)acetamide (2) was prepared. Compound (2) underwent cyclization upon heating in ethanolic sodium ethoxide solution to give the corresponding cyclized form 3-amino- $N$-(4-chlorophenyl)-4,6-distyrylthieno[2,3b]pyridine-2-carboxamide (3). The elemental analyses and spectroscopic data of compounds (2) and (3) are in agreement with their proposed structures. Their insecticidal activity against cowpea aphid, Aphis craccivora Koch, was studied. The results of insecticidal activity for compounds (2) and (3) against the nymphs and the adults of the tested insects exhibited that compounds (2) and (3) have a higher insecticidal activity than that of acetamiprid, a reference insecticide, after $24 \mathrm{~h}$ of treatment.
\end{abstract}

\section{Introduction}

The chemistry of functionalised pyridine compounds has been extensively developed, which is reflected in many papers that have been published. ${ }^{1-8}$ This is associated with both a theoretical interest in this class of organic compounds and a very broad spectrum of the practical uses of pyridine derivatives. For example, more than $10 \%$ of the most commonly used modern medicines contain pyridine or the hydrogenated pyridine ring. ${ }^{9}$

A lot of neonicotinoids insecticides contain pyridine ring in their structure and at the present time the use of these insecticides is increased in the field of crop protection as a result of their different advantages. ${ }^{10-15}$ As an Expanding our work that focused on the synthesis of heterocyclic compounds and continuing our investigations on the chemistry of some pyridine derivatives neonicotinoid analogs, ${ }^{1-6}$ we report herein the synthesis of two new heterocyclic compounds containing pyridine ring

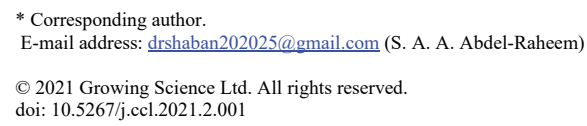


and screened their insecticidal activity against cowpea aphid, Aphis craccivora Koch (Homoptera: Aphididae) in the presence of acetamiprid insecticide as a reference.

\section{Results and Discussion}

\subsection{Chemistry}

Compounds $\mathbf{2}$ and $\mathbf{3}$ were synthesized here as a result of the well known biological activity of the compounds containing pyridine moiety. Reaction of compound (1) "3-cyano-4,6-distyrylpyridin-2(1H)thione", which was prepared according to the reported method, ${ }^{6}$ with 2-chloro- $N-(4-$ chlorophenyl)acetamide in ethanol containing slightly excess amounts of fused sodium acetate for 30 min afforded the compound 2-((3-Cyano-4,6-distyrylpyridin-2-yl)thio)acetamide (2). The chemical structure of compound $\mathbf{2}$ was confirmed by elemental and spectral analysis. Compound $\mathbf{2}$ underwent intramolecular Thorpe-Ziegler cyclization upon heating in ethanol containing catalytic amounts of sodium ethoxide for $5 \mathrm{~min}$ to give the corresponding cyclized form 3-Amino- $N$-(4-chlorophenyl)-4,6distyrylthieno[2,3-b]pyridine-2-carboxamide (3) (see Fig. 1). Spectroscopic data and elemental analyses of compound $\mathbf{3}$ were in agreement with its proposed structure.

IR spectrum of compound 2 showed absorption bands at 3292, 2216 and $1662 \mathrm{~cm}^{-1}$ characteristics for $(\mathrm{NH}),(\mathrm{C} \equiv \mathrm{N})$ and $(\mathrm{C}=\mathrm{O})$ groups respectively. The absorption band of $(\mathrm{C} \equiv \mathrm{N})$ of compound 2 was disappeared when cyclised to give the thienopyridine 3 and was replaced by 3462 and $3408 \mathrm{~cm}^{-1}$ for $\mathrm{NH}_{2} .{ }^{1} \mathrm{H}$ NMR spectrum (DMSO- $d_{6}, 400 \mathrm{MHz}$ ) of compound 2 showed singlet signals at 10.51 and 4.27 for $(\mathrm{NH})$ and $\left(\mathrm{CH}_{2}\right)$ groups respectively. The signal of $\left(\mathrm{CH}_{2}\right)$ group of compound 2 was disappeared when cyclised to give compound 3. DEPT 135 (DMSO-d6, $100 \mathrm{MHz}$ ) spectrum of compound 2 showed characteristic signal at 35.36 for $\left(\mathrm{CH}_{2}\right)$ group which disappeared when cyclised to give compound $\mathbf{3}$.

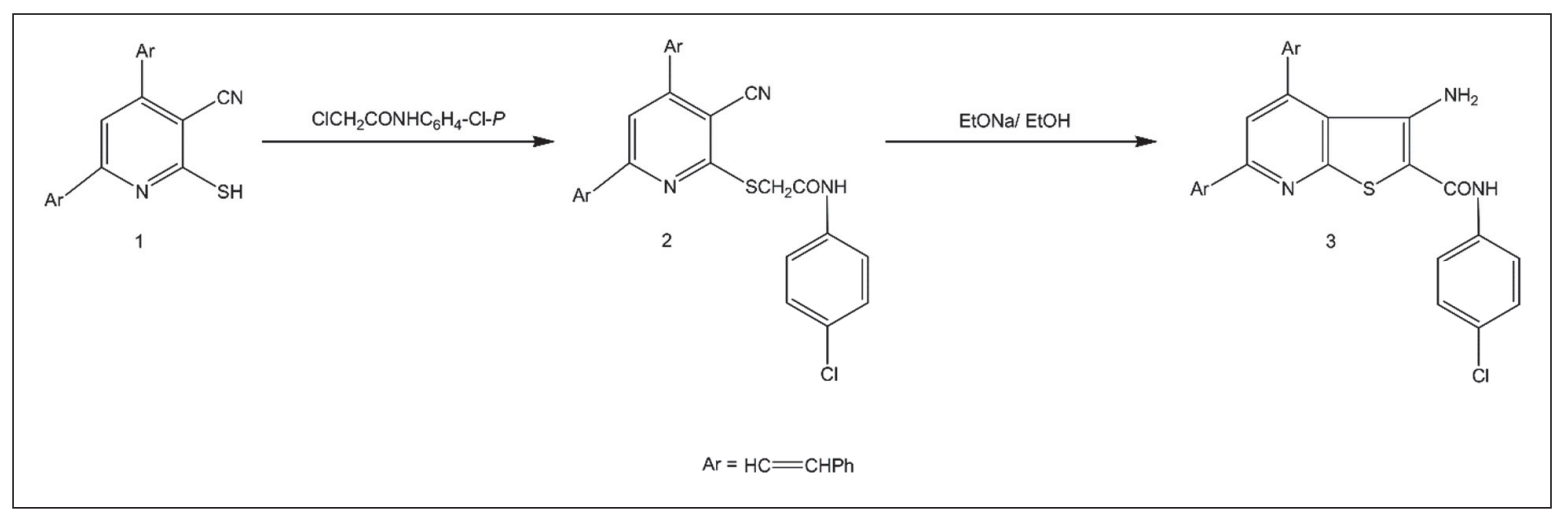

Fig. 1. Synthesis of compounds 2 and $\mathbf{3}$.

\subsection{Insecticidal activity of compounds 2 and 3.}

\subsubsection{Insecticidal activity test for the cowpea aphid nymphs.}

Compounds $\mathbf{2}$ and $\mathbf{3}$ were tested for their insecticidal activity against the nymphs of the collected aphids and the results are presented in Table 1 . After $24 \mathrm{~h}$, insecticidal activity data showed that compounds $\mathbf{2}$ and $\mathbf{3}$ exhibited strong to weak insecticidal activity against nymphs of cowpea aphid and the $\mathrm{LC}_{50}$ values were 0.029 and $0.040 \mathrm{ppm}$, respectively, whereas the $\mathrm{LC}_{50}$ value of acetamiprid was $0.045 \mathrm{ppm}$. After $48 \mathrm{~h}$ of test, it is found that the insecticidal activity of compounds $\mathbf{2}$ and $\mathbf{3}$ against nymphs of cowpea aphid, Aphis craccivora Koch ranged from good to moderate and $\mathrm{LC}_{50}$ values were 0.006 and $0.007 \mathrm{ppm}$, respectively, whilst the $\mathrm{LC}_{50}$ value of acetamiprid $0.006 \mathrm{ppm}$. These results indicate that compounds $\mathbf{2}$ and $\mathbf{3}$ have excellent insecticidal activity compared with the insecticidal 
activity of acetamiprid insecticide because the toxic ratio of compounds $\mathbf{2}$ and $\mathbf{3}$ is more than that of acetamiprid after $24 \mathrm{~h}$ of test.

Table 1. Insecticidal activity of acetamiprid and compounds $\mathbf{2}$ and $\mathbf{3}$ against the cowpea aphid nymphs after 24 and $48 \mathrm{~h}$ of treatment.

\section{$24 \mathrm{~h}$ after treatment}

$48 \mathrm{~h}$ after treatment

\begin{tabular}{ccccccc}
\hline Compd & Slope \pm SE & $\begin{array}{c}\text { LC } \\
(\mathbf{p p m})\end{array}$ & $\begin{array}{c}\text { Toxic } \\
\text { ratio }\end{array}$ & Slope \pm SE & $\mathbf{L C}_{\mathbf{5 0}}(\mathbf{p p m})$ & $\begin{array}{c}\text { Toxic } \\
\text { ratio }\end{array}$ \\
\hline Acetamiprid & $0.34 \pm 0.02$ & 0.045 & 1 & $0.42 \pm 0.03$ & 0.006 & 1 \\
$\mathbf{2}$ & $0.41 \pm 0.03$ & 0.029 & 1.552 & $0.49 \pm 0.04$ & 0.006 & 1 \\
$\mathbf{3}$ & $0.40 \pm 0.03$ & 0.040 & 1.125 & $0.47 \pm 0.04$ & 0.007 & 0.857 \\
\hline
\end{tabular}

Notes: toxic ratio is defined as the ratio of acetamiprid's $\mathrm{LC}_{50}$ value for baseline toxicity and the compound's $\mathrm{LC}_{50}$ value.

\subsubsection{Insecticidal activity test for the cowpea aphid adults}

Compounds $\mathbf{2}$ and $\mathbf{3}$ were tested for their insecticidal activity against the adults of the gathered aphids and the results are in Table 2. The results showed that after $24 \mathrm{~h}$ of test, compounds $\mathbf{2}$ and $\mathbf{3}$ have strong to weak activity and $\mathrm{LC}_{50}$ values were 0.149 and $0.183 \mathrm{ppm}$, respectively, whilst the $\mathrm{LC}_{50}$ value of acetamiprid was $0.225 \mathrm{ppm}$. After $48 \mathrm{~h}$ of insecticidal activity test, the insecticidal activity of compounds 2 and 3 varied from high to low and $\mathrm{LC}_{50}$ values were 0.017 and $0.022 \mathrm{ppm}$, respectively, against cowpea aphid adults, whilst $0.023 \mathrm{ppm}$ was the $\mathrm{LC}_{50}$ value of acetamiprid. The above results revealed that the insecticidal activity of compounds $\mathbf{2}$ and $\mathbf{3}$ against adults of cowpea aphid was more than that of acetamiprid after 24 and $48 \mathrm{~h}$ of treatment.

Table 2. Insecticidal activity of acetamiprid and compounds $\mathbf{2}$ and $\mathbf{3}$ against the cowpea aphid adults after 24 and $48 \mathrm{~h}$ of treatment

\section{$24 \mathrm{~h}$ after treatment $48 \mathrm{~h}$ after treatment}

\begin{tabular}{ccccccc}
\hline Compd & Slope $\pm \mathbf{S E}$ & $\mathbf{L C}_{\mathbf{5 0}}(\mathbf{p p m})$ & Toxic & Slope $\pm \mathbf{S E}$ & $\mathbf{L C}_{\mathbf{5 0}}(\mathbf{p p m})$ & $\begin{array}{c}\text { Toxic } \\
\text { ratio }\end{array}$ \\
& & & & & ratio \\
\hline Acetamiprid & $0.24 \pm 0.02$ & 0.225 & 1 & $0.32 \pm 0.03$ & 0.023 & 1 \\
$\mathbf{2}$ & $0.36 \pm 0.03$ & 0.149 & 1.510 & $0.38 \pm 0.03$ & 0.017 & 1.353 \\
$\mathbf{3}$ & $0.36 \pm 0.03$ & 0.183 & 1.229 & $0.40 \pm 0.03$ & 0.022 & 1.045 \\
\hline
\end{tabular}

Notes: toxic ratio is defined as the ratio of acetamiprid's $\mathrm{LC}_{50}$ value for baseline toxicity and the compound's $\mathrm{LC}_{50}$ value.

\subsubsection{Structure-action relationship}

According to the general framework structure of the used compounds $\mathbf{2}$ and $\mathbf{3}$, it appears that the compound $N$-(4-chlorophenyl)-2-((3-cyano-4,6-distyrylpyridin-2-yl)thio)acetamide (2) is more active than the compound 3-amino- $N$-(4-chlorophenyl)-4,6-distyrylthieno[2,3-b]pyridine-2-carboxamide (3) against the cowpea aphids. The high activity associated with compound $\mathbf{2}$ may be due to the presence of the opened form structure in compound $\mathbf{2}$ and the presence of cyano group, but compound $\mathbf{3}$ was found in the cyclized form and cyano group is absent in its structure. 


\section{Conclusion}

In this work, two heterocyclic compounds namely, $N$-(4-chlorophenyl)-2-((3-cyano-4,6distyrylpyridin-2-yl)thio)acetamide (2) and 3-amino- $N$-(4-chlorophenyl)-4,6-distyrylthieno[2,3b]pyridine-2-carboxamide (3), have been prepared in pure state and their insecticidal activity against cowpea aphid, Aphis craccivora Koch was evaluated. The results of this insecticidal activity illustrated that these compounds have a higher activity against cowpea aphid than that of acetamiprid insecticide and this emphasizes the importance of pyridine compounds in the agricultural uses.

\section{Experimental}

\subsection{Materials and methods}

Melting points were determined by using a Fisher-Johns apparatus for the compounds 2 and 3. Elemental analysis $(\mathrm{C}, \mathrm{H}, \mathrm{N}$, and $\mathrm{S})$ was determined by a Vario EL C, H, N, S analyzer. DEPT $135,{ }^{1} \mathrm{H}$ $\mathrm{NMR}$ and ${ }^{13} \mathrm{C}$ NMR spectra measurement were accomplished via a Bruker $400 \mathrm{MHz}$ spectrometer in the presence of tetramethylsilane (TMS) as an internal reference. Infrared (IR) spectra were determined by a Pye-Unicam SP3-100 spectrophotometer using the $\mathrm{KBr}$ disk technique. Thin-layer chromatography (TLC) was used for the purity check of the synthesized compounds and $\delta(\mathrm{ppm})$ is the unit of chemical shifts. The field strain of cowpea aphids was collected from faba bean, Vicia faba L., fields of the experimental farm of Assiut University. Compound 1 was prepared according to the reported method ${ }^{6}$ and the acetamiprid insecticide was purchased from Sigma-Aldrich (France). Acetamiprid insecticide and compounds ( 2 and $\mathbf{3}$ ) were tested against the collected cowpea aphid, Aphis craccivora Koch.

4.2 Synthetic procedure for N-(4-chlorophenyl)-2-((3-cyano-4,6-distyrylpyridin-2-yl)thio)acetamide (2).

A mixture of compound (1) (2 g, $0.006 \mathrm{~mol}), 2$-chloro- $N$-(4-chlorophenyl)acetamide (1.2 g, 0.006 $\mathrm{mol})$, and fused sodium acetate $(0.6 \mathrm{~g}, 0.007 \mathrm{~mol})$ in ethanol $(25 \mathrm{~mL})$ was heated under reflux for 30 $\mathrm{min}$. The formed precipitate was collected and recrystallized from ethanol-dioxane mixture $(1: 2)$ as Pale orange crystals of compound 2. Yield: $85 \%$. m. p. $224-225^{\circ} \mathrm{C}$. IR $(v)(\mathrm{KBr}) \mathrm{cm}^{-1}: 3292(\mathrm{NH}), 2921(\mathrm{C}-$ $\mathrm{H}$ aliphatic), $2216(\mathrm{C} \equiv \mathrm{N}), 1662(\mathrm{C}=\mathrm{O}) .{ }^{1} \mathrm{H}$ NMR (DMSO- $\left.d_{6}, 400 \mathrm{MHz}\right): \delta 10.51(\mathrm{~s}, 1 \mathrm{H}, \mathrm{NH}), 7.21-$ $7.84(\mathrm{~m}, 19 \mathrm{H}, 2 \mathrm{CH}=\mathrm{CH}$ and $\mathrm{Ar}-\mathrm{H}), 4.27\left(\mathrm{~s}, 2 \mathrm{H}, \mathrm{CH}_{2}\right) .{ }^{13} \mathrm{C}$ NMR (DMSO-d6, $\left.100 \mathrm{MHz}\right): \delta 165.83$, $162.01,157.37,155.81,149.56,136.17,135.70,132.78,130.77,129.54,129.26,128.04,127.88$, $126.89,122.21,115.42,114.65,114.39,101.83,35.36$. DEPT 135 (DMSO- $\left.d_{6}, 100 \mathrm{MHz}\right): \delta 135.70$ $(\mathrm{CH}), 132.78(\mathrm{CH}), 129.54(\mathrm{CH}), 129.26(\mathrm{CH}), 128.04(\mathrm{CH}), 127.88(\mathrm{CH}), 126.87(\mathrm{CH}), 122.23(\mathrm{CH})$, $114.65(\mathrm{CH}), 113.39(\mathrm{CH}), 35.36\left(\mathrm{CH}_{2}\right)$. Elemental Analysis Calculated for $\mathrm{C}_{30} \mathrm{H}_{22} \mathrm{ClN}_{3} \mathrm{OS}(\%)$ : $\mathrm{C}$, 70.92; H, 4.36; N, 8.27; S, 6.31. Found (\%): C, 70.95; H, 4.41; N, 8.25; S, 6.33.

\subsection{Synthetic procedure for 3-Amino-N-(4-chlorophenyl)-4,6-distyrylthieno[2,3-b]pyridine-2-} carboxamide (3).

Compound (2) (2.5 g, $0.005 \mathrm{~mol})$ were suspended in sodium ethoxide solution $(0.5 \mathrm{~g}$ of sodium in $31 \mathrm{~mL}$ of absolute ethanol) and heated for 5 min under reflux. The formed product after cooling was collected and recrystallized from ethanol-dioxane mixture (1:2) as orange crystals of compound 3. Yield: $89 \%$. m. p. $243-244^{\circ} \mathrm{C}$. IR (v) (KBr) cm${ }^{-1}: 3462,3408,3326\left(\mathrm{NH}, \mathrm{NH}_{2}\right), 3025(\mathrm{C}-\mathrm{H}$ aromatic), 2921, 2850 (C-H aliphatic), 1647 (C=O). ${ }^{1} \mathrm{H}$ NMR (DMSO- $\left.d_{6}, 400 \mathrm{MHz}\right): \delta 9.61$ (s, 1H, NH), 6.96$8.04\left(\mathrm{~m}, 21 \mathrm{H}, 2 \mathrm{CH}=\mathrm{CH}, \mathrm{NH}_{2}\right.$ and $\left.\mathrm{Ar}-\mathrm{H}\right) .{ }^{13} \mathrm{C}$ NMR (DMSO- $\left.d_{6}, 100 \mathrm{MHz}\right): \delta 161.53,158.01,155.37$, $144.67,136.98,136.27,134.34,133.18,133.08,129.28,128.09,127.73,123.76,123.67,122.69$, 122.37, 121.99, 121.79, 117.58. DEPT 135 (DMSO- $d 6,100 \mathrm{MHz}): \delta 134.33(\mathrm{CH}), 133.18(\mathrm{CH}), 129.28$ $(\mathrm{CH}), 123.75(\mathrm{CH}), 123.67(\mathrm{CH}), 122.69(\mathrm{CH}), 122.37(\mathrm{CH}), 121.99(\mathrm{CH}), 121.79(\mathrm{CH}), 117.58(\mathrm{CH})$. 
Elemental Analysis Calculated for $\mathrm{C}_{30} \mathrm{H}_{22} \mathrm{ClN}_{3} \mathrm{OS}(\%)$ : C, 70.92; H, 4.36; N, 8.27; S, 6.31. Found (\%): C, 70.94; H, 4.35; N, 8.31; S, 6.32.

\subsection{Laboratory bioassay}

The insecticidal activity for the aforementioned compounds $\mathbf{2}$ and $\mathbf{3}$ was checked via leaf dip bioassay method. ${ }^{16}$ The concentration of these chemical compounds that is required to kill $50 \%$ ( $\mathrm{LC}_{50}$ ) of cowpea aphid, Aphis craccivora Koch was reported here. In this experiment, six concentrations of compounds 2 and 3 plus $0.1 \%$ Triton X-100 as a surfactant were used and a total of 20 adults and 20 nymphs, approximately of the same size, were dipped for 10 seconds in each concentration three times. The treated aphids were allowed to dry at room temperature for about $0.5 \mathrm{~h}$. Control batches of aphids were similarly dipped in a solution of distilled water plus $0.1 \%$ Triton X-100. Then, after drying of the treated batches of cowpea aphids, they were transferred to Petri dishes $(9 \mathrm{~cm}$ diameter) and held for 24 and $48 \mathrm{~h}$ at $22+2{ }^{\circ} \mathrm{C}, 60+5 \%$ relative humidity, and photoperiod of 12:12 (light/dark). Recording aphid mortality was 24 and $48 \mathrm{~h}$ after treatment by using a binocular microscope. The aphid that was unable to coordinate forward movement was considered dead. Insecticidal activity test of compounds 2 and 3 was repeated twice and the results were corrected using Abbott's formula. ${ }^{17}$ Median lethal concentrations ( $\mathrm{LC}_{50}$ ) and slope values of compounds $\mathbf{2}$ and $\mathbf{3}$ were determined by the Probit regression analysis program and expressed in parts per million (ppm). ${ }^{18}$

\section{References}

1. Bakhite E. A., Abd-Ella A. A., El-Sayed M. E. A., and Abdel-Raheem Sh. A. A. (2014) Pyridine derivatives as insecticides. Part 1: Synthesis and toxicity of some pyridine derivatives against Cowpea Aphid, Aphis craccivora Koch (Homoptera: Aphididae). J. Agric. Food Chem., 62 (41) 9982-9986.

2. Bakhite E. A., Abd-Ella A. A., El-Sayed M. E. A., and Abdel-Raheem Sh. A. A. (2017) Pyridine derivatives as insecticides. Part 2: Synthesis of some piperidinium and morpholinium cyanopyridinethiolates and their Insecticidal Activity. J. Saud. Chem. Soc., 21 (1) 95-104.

3. Kamal El-Dean A. M., Abd-Ella A. A., Hassanien R., El-Sayed M. E. A., Zaki R. M., and AbdelRaheem Sh. A. A. (2019) Chemical design and toxicity evaluation of new pyrimidothienotetrahydroisoquinolines as potential insecticidal agents. Toxicol. Rep., 6 100-104.

4. Abdel-Raheem Sh. A. A., Kamal El-Dean A. M., Hassanien R., El-Sayed M. E. A., and Abd-Ella A. A. (2021) Synthesis and characterization of some distyryl-derivatives for agricultural uses. Eur. Chem. Bull., 10 (1) 35-38.

5. Abdel-Raheem Sh. A. A., Kamal El-Dean A. M., Hassanien R., El-Sayed M. E. A., and Abd-Ella A. A. (2020) Synthesis and biological activity of 2-((3-Cyano-4,6-distyrylpyridin-2-yl)thio)acetamide and its cyclized form. Alger. j. biosciences, 01 (02) 046-050.

6. Kamal El-Dean A. M., Abd-Ella A. A., Hassanien R., El-Sayed M. E. A., and Abdel-Raheem Sh. A. A. (2019) Design, Synthesis, Characterization, and Insecticidal Bioefficacy Screening of Some New Pyridine Derivatives. ACS Omega, 4 (5) 8406-8412.

7. Zaki R. M., Kamal El-Dean A. M., Mickey J. A., Marzouk N. A., and Ahmed R. H. (2017) Synthesis, reactions, and antioxidant activity of 3-(pyrrol-1-yl)-4,6-dimethyl selenolo[2,3-b]pyridine derivatives. Synth. Commun., 47 (24) 2406-2416.

8. Altaf A. A., Shahzad A., Gul Z., Rasool N., Badshah A., Lal B., and Khan E. A (2015) Review on the Medicinal Importance of Pyridine Derivatives. J. Drug Des. Med. Chem., 1 (1) 1-11.

9. Lukevits É. (1995) Pyridine derivatives in the drug arsenal (150 years of pyridine chemistry). Chem. Heterocycl. Compd., 31 (6) 639-650.

10. Zhang N., Tomizawa M., and Casida J. E. (2004) $\alpha$-Nitro Ketone as an Electrophile and Nucleophile: Synthesis of 3-Substituted 2-Nitromethylenetetrahydrothiophene and tetrahydrofuran as Drosophila Nicotinic Receptor Probes. J. Org. Chem., 69 (3) 876-881. 
11. Shimomura M., Yokota M., Ihara M., Akamatsu M., Sattelle D. B., and Matsuda K. (2006) Role in the Selectivity of Neonicotinoids of Insect-Specific Basic Residues in Loop D of the Nicotinic Acetylcholine Receptor Agonist Binding Site. Mol. Pharmacol., 70 (4) 1255-1263.

12. Tomizawa M., and Casida J. E. (2003) Selective toxicity of neonicotinoids attributable to specificity of insect and mammalian nicotinic receptors. Annu. Rev. Entomol., 48 339-364.

13. Tomizawa M., Talley T., Maltby D., Durkin K. A., Medzihradszky K. F., Burlingame A. L., Taylor P., and Casida J. E. (2007) Mapping the elusive neonicotinoid binding site. Proc. Natl. Acad. Sci. U.S.A., 104 (21) 9075-9080.

14. Kagabu S., Ishihara R., Nishimura K., and Naruse Y. (2007) Insecticidal and neuroblocking potencies of variants of the imidazolidine moiety of imidacloprid-related neonicotinoids and the relationship to partition coefficient and charge density on the pharmacophore. J. Agric. Food Chem., 55 (3) 812-818.

15. Yang Z. B., Hu D. Y., Zeng S., and Song B. A. (2016) Novel hydrazone derivatives containing pyridine amide moiety: Design, synthesis, and insecticidal activity. Bioorg. Med. Chem. Lett., 26 (4) 1161-1164.

16. O’Brien P. J., Abdel-Aal Y. A., Ottea J. A., and Graves J. B. (1992) Relationship of insecticide resistance to carboxylesterases in Aphis gossypii (Homoptera: Aphididae) from Midsouth cotton. $J$. Econ. Entomol., 85 (3) 651-657.

17. Abbott W. S. (1925) A method of computing the effectiveness of an insecticide. J. Econ. Entomol., 18 (2) $265-267$.

18. Finney D. J. (1952) Probit Analysis: A Statistical Treatment of the Sigmoid Response Curve, 2nd Ed, Cambridge Univ. Press, Cambridge, U. K.

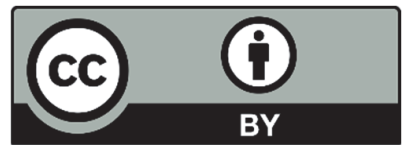

(C) 2021 by the authors; licensee Growing Science, Canada. This is an open access article distributed under the terms and conditions of the Creative Commons Attribution (CC-BY) license (http://creativecommons.org/licenses/by/4.0/). 